\title{
Poetic justice: ensuring a place for Ulster-Scots literature within the school curriculum in the north of Ireland
}

\section{Carol Baraniuk}

\section{OpenEdition}

\section{Journals}

Electronic version

URL: http://journals.openedition.org/etudesirlandaises/3526

DOI: 10.4000/etudesirlandaises.3526

ISSN: 2259-8863

Publisher

Presses universitaires de Rennes

Printed version

Date of publication: 20 December 2013

Number of pages: $55-73$

ISBN: 978-2-7535-2887-1

ISSN: 0183-973X

\section{Electronic reference}

Carol Baraniuk, « Poetic justice: ensuring a place for Ulster-Scots literature within the school curriculum in the north of Ireland », Études irlandaises [Online], 38-2 | 2013, Online since 20 December 2015, connection on 02 May 2019. URL : http://journals.openedition.org/etudesirlandaises/3526 ;

DOI : 10.4000/etudesirlandaises.3526

This text was automatically generated on 2 May 2019.

(c) Presses universitaires de Rennes 


\title{
Poetic justice: ensuring a place for Ulster-Scots literature within the school curriculum in the north of Ireland
}

\author{
Carol Baraniuk
}

1 One of the finest entries in the Ulster-Scots literary canon is "The Irish Cottier's Death and Burial". This work, executed in the demanding Spenserian stanza and employing fairly dense Ulster Scots, emanates from the pen of James Orr (1770-1816), a County Antrim handloom weaver and Presbyterian United Irishman. Not published until after his death, it portrays in moving and affectionate detail a whole community involved in the intimate rituals and interactions that progressively accompany the deathbed, wake and interment of one of the poorest of their number. It is without question a master work, which eschews the sentimentality of Robert Burns's "The Cotter's Saturday Night", a poem with which it implicitly dialogues, and which had itself been inspired by Robert Fergusson's "The Farmer's Ingle", a celebration of virtuous thrift and hard work among the rural labouring classes in eighteenth-century Scotland.

2 Orr's poem foregrounds proudly the worth, dignity, resolution and independence of his dying Cottier, but encoded within the narrative of his passing are Orr's fears for the vibrant society he portrays so powerfully, and which he believes is under threat from poverty and neglect during the post-1801 Union era when this northern Irish, UlsterScots community, of which the forlorn Cottier is a symbol, lacks the advocacy of powerful friends within the metropolitan establishment. In the poem's closing stanzas the setting shifts to the burial ground and Orr's verse rises to an awful, tragic sublime, as the narrator depicts the disintegration to mere bone and skull of beloved deceased kinsfolk, thus confronting his readers with the great abyss of mortality, and pre-echoing the bleakness of modernist perspectives on the human condition':

An' while the sexton earth'd his poor remains,

The circling crowd contemplatively stood,

An' mark'd the empty sculls, an' jointless banes,

That, cast at random, lay like cloven wood: 
Some stept outbye, an' read the gravestanes rude,

That only tald the inmates' years an' names;

An 'ithers, kneeling, stream'd a saut, saut flood,

On the dear dust that held their kinsfolks' frames.

3 The setting may be linked to a particular locality, but the themes are universal, and the work is exceptionally finely crafted. It is a piece which any nation might be proud to own within its national literature, and yet outside a few specialised academic circles in the north of Ireland and Scotland, it is hardly known. The following essay has been composed to challenge the inertia of educationalists and policy makers which has permitted the perpetuation of such ignorance, marginalised the works of some of Ireland's finest writers and denied the rising generation access to the fullness of its cultural heritage.

Since the sea corridor separating the east coast of the province of Ulster from the west of Scotland is a mere twelve miles wide at its narrowest point it is small wonder that a dynamic relationship, co-operative or combative by turns, has existed between these two regions since prehistoric times. Following a period of raids and colonisation in the late fifth century, for example, the Gaelic kingdom of Dalriada covered territory that extended from the Glens of Antrim across the North Channel to include Kintyre, Argyle and some of the western islands - an arrangement that eventually enabled the establishment of Columcille's Christian monastic settlement on Iona ${ }^{2}$. Later, during the plantations era of the late sixteenth and early seventeenth centuries, Scots-speaking Lowlanders from Scotland's Central Belt began arriving in Ulster, taking the opportunities offered by both private and government-sponsored schemes to acquire land and thereby greater prosperity. If such settlers may be deemed economic migrants, their numbers were swollen within a few generations by asylum-seeking Presbyterian Covenanters who were fleeing persecution visited on them in Scotland by the Stuart monarch Charles II as he attempted to assert the supremacy of the Crown over the Kirk the Scottish national church ${ }^{3}$.

5 The communities established by such Scots migrants to Ulster developed a significantly different character from those of their neighbours, whether these were native Irish or English-descended. Their language, cultural practices and for the most part their religion - Presbyterianism - derived from their parent communities in the Scottish Lowlands. Though regarded by the Irish as colonists, for at least two centuries they maintained an ethos that to the governing authorities appeared robustly anti-establishment and indeed some two thirds of their number supported the United Irish cause in the short-lived and bloody 1798 Rebellion. The writers of the Irish Ordnance Survey Memoirs during the 1830 s and 40 s commented on this history, and at some length on the perceived "otherness" of the Ulster-Scots districts they visited, describing the people's speech as "disagreeably Scottish" or "broad and coarse". Their manners too were deemed "dry and uncommunicative", while their traditional music was thought to be lacking in originality: "They have not any national music: their songs are merely the common ballads of the country and their airs are Scottish". The enthusiasm for theology and disputation of scripture central to Presbyterian life was also viewed with patent disapproval: "They have much taste for reading [...] works on theology and divinity such as might in every respect be deemed beyond their comprehension and as unsuited to their taste".

6 Undoubtedly such comments reveal a class-based bias against members of the lower orders who were literate, confident and deemed to be lacking in deference. They also betray an Anglo-centric preference for standard register speech. The development of a 
state-backed education system in the later nineteenth century served this homogenising trend well, as is evident from a report made in the 1880s which commended the "wellmanaged" schools responsible for the near eradication of "the Scotch accent and the dialect words"5. But if Scots speech was considered only fit for the farmyard and "managed" often through a system of corporal punishment in the classroom, it proved more resilient within the home and continued to be employed in everyday discourse even while regarded as a low status vernacular by officialdom. In addition, its speakers had access to sophisticated literary works in Scots by writers from earlier periods such as Alexander Montgomerie, Sir David Lindsay and John Barbour, and in the era of the vernacular revival to the poetry of Allan Ramsay, Robert Fergusson and Robert Burns ${ }^{6}$.

7 By the 1940s, the Scots-speaking population was concentrated in four main heartlands within the historic province of Ulster: the Laggan district of east Donegal, north-west Derry, north-east Down including the Ards Peninsula, and much of county Antrim. At this period the likely disappearance of the Scotch accent and the dialect words began to be viewed as a matter of concern, at least by some academics and cultural activists who began undertaking and documenting detailed research into local speech. The papers published in Ulster Dialects: An Introductory Symposium ${ }^{7}$ recorded the findings of a generation of highly respected scholars - Brendan Adams, John Braidwood and Robert Gregg - who researched extensively the nature of Scots and English employed in Ulster, and the relationship between the different speech types ${ }^{8}$. Braidwood noted the dominance of Scots within the Province: "It seems to be a fact that the Ulster English dialects have suffered more encroachment from Scots than the reverse". Robert Gregg, originally from Larne, County Antrim and eventually Head of the Linguistics Department at the University of British Columbia, mapped the areas of Ulster where Scots language was employed at greatest density, while Brendan Adams, Dialect Archivist of the Ulster Folk Museum, discussed the close relationship between Ulster Scots and the Scots language spoken in parts of Scotland, commenting: "The north-eastern or Ulster Scots dialect [...] an offshoot of the Central Scots dialect as spoken in Galloway, Ayrshire and Renfrewshire [...] still preserves the marks of its Scottish ancestry in most of the areas in which it is spoken ${ }^{10}$."

8 The term "dialect" is used here to refer to regional variations of the Scots language within Ulster and Scotland, not to imply that Scots itself is a dialect of English. John Corbett, until recently a linguist within the Scottish Language Department of the University of Glasgow offers the following useful assessment of the relationship between Scots and English: "Scots has always been a hybrid language - a mixture of Old English, Old Norse and French, with lesser borrowings from other languages, for example Gaelic. Scots and English are not two monolithic and distinct systems, but a range of varieties which sometimes diverge but have much in common ${ }^{11}$."

The robust nature of Ulster Scots is clearly evident from its generation of a vibrant literary tradition which, though it looks to Scotland for its models and genres, evinces its own strong, distinctive character and addresses local, national and global issues on its own terms. During the same period in which linguistic scholars were observing and recording the continuing influence of Scots language in the north of Ireland, John Hewitt, poet, critic and regionalist cultural commentator was engaged in recovering the indigenous Ulster-Scots poetic tradition, many of whose practitioners inhabited the areas where Scots was spoken and who when expressing themselves in verse frequently, though not exclusively, employed the vernacular Braid Scotch with which they and their 
neighbours communicated in daily life. Hewitt's research, originally undertaken in pursuit of his MA thesis Ulster Poets, (1949) uncovered forgotten collections of "little books" of poetry in the stacks of the Linen Hall Library and the Belfast Public Library. Many had been published in the late eighteenth or early nineteenth centuries by labouring-class writers associated with the linen industry; their efforts to appear in print had in many cases been supported and funded through the subscriptions of their neighbours. Hewitt's tireless promotion of these works among scholars and in popular culture by means of letters, journal articles and radio talks, reminded the Ulster public that not only did the north of Ireland possess a significant Scots language inheritance, it also owned a literary heritage originally deriving from the rich and distinguished Scottish literary tradition.

Hewitt, himself a fine poet whose work in the later twentieth century thoughtfully addressed the northern Irish "troubles"12", was deeply conscious of the "buried men/ in Ulster clay" who had made the north of Ireland their home and over generations shaped its character ${ }^{13}$. His thesis described "a period of surprising poetic activity on many levels, including peasants and craftsmen ${ }^{14}$ ". Many of his writers were resident in the UlsterScots heartlands that the linguist Robert Gregg would later map and document, and their work demonstrated in a variety of ways - in linguistic registers, or through religious and other cultural references - their Scottish heritage, even as they identified with their Irish homeland. In the words of Samuel Thomson (1766-1816), one of the most talented Ulster poets of the Romantic period, they were "Irish without" and "Scotch within ${ }^{15 "}$.

Hewitt explored early editions of Ulster-Scots vernacular writers such as James Orr, the Bard of Ballycarry and David Herbison of Dunclug (both weavers), Francis Boyle of Gransha (a blacksmith) and many more. Self-avowedly left-wing in his own politics, Hewitt welcomed enthusiastically poetry often written by individuals from the labouringclasses which recorded concerns and practices pertinent to community life in rural Ulster. Take for example David Herbison's "Auld Wife" who laments the decline of the cottage linen industry and with it the independence it afforded to the laboring classes, many of whom are now forced to emigrate in search of employment. As she speaks what began as apparently an old woman's simple nostalgia develops into a powerful lament for the state of the nation ${ }^{16}$ :

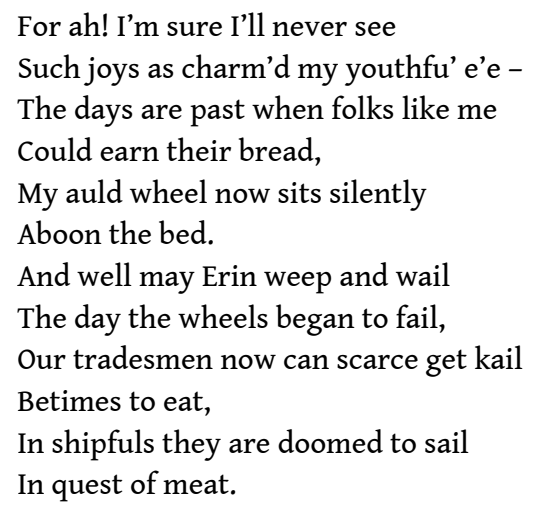

Hewitt's research was eventually published in 1974 as Rhyming Weavers and Other Country Poets of Antrim and Down and was re-issued in 2004. Until the appearance of the larger and more broadly based Ulster-Scots Writing: An Anthology in 2008 ${ }^{17}$, it remained the best introduction to the Ulster-Scots poetic tradition. The Anthology project has permitted the breadth, longevity and variety of the Ulster-Scots literary tradition to begin to be appreciated. It incorporates drama and nineteenth-century prose fiction, much with a 
strong vernacular element while also offering a selection of theological writing and powerful sermons. It includes a variety of texts by contemporary writers and in addition showcases pieces by writers such as Seamus Heaney who would not profess an UlsterScots identity, but whose engagement with Scottish and Ulster-Scots literature and language traditions further authenticates their place within the cultural heritage of the north of Ireland.

So, since Ulster-Scots poetry has a long history, and is rooted in linguistic habits and cultural practices demonstrably belonging to Ireland's northern province why has it received so little attention within education? When we consider its reception more generally, it becomes clear that a critical tradition developed within and beyond Ireland that has failed to do justice to Ulster-Scots writers. Towards the end of the nineteenth century insufficiently informed judgements dismissed Ulster vernacular verse as an interesting but derivative, curiosity. D. J. O'Donoghue (1866-1917) provides an example that reveals either his ignorance of a vernacular Scots tradition with generic characteristics, or at least his failure to observe with what originality and sophistication Scots language and stanza forms have been employed by the best Ulster poets. In a discussion of "the dialect poets", including James Orr and Hugh Porter he commends, if patronisingly: "Some of these are excellent and simply because they are so homely and natural." Then comes a damning generalisation, all the more reprehensible because it is indiscriminately applied: "It must be admitted, though, that the dialect poets too often slavishly imitated Burns"18. The "Burns imitator" tag appears to have been retained in popular imagination for the following dismissal of Ulster-Scots literature, breath-taking in its assurance, appeared in a Belfast-based newspaper during the 1990s: "there is [...] virtually no literature originating in Ulster apart from the weaver poets, mainly James Orr of Ballycarry and he was a Burns imitator ${ }^{19}$ ". Even the distinguished Scots scholar and critic, Liam McIlvanney, while allowing that the best Ulster-Scots poets were striking and original writers, could add: "From the perspective of Burns scholars, however, the most conspicuous feature of the Ulster poets is their unrestrained bardolatry ${ }^{20}$." In a more recent essay, however, Mcllvanney offered a nuanced and thoughtful estimate of the work of James Orr, and of the significance of the Ulster-Scots poetic tradition, paying tribute to its ability to "complicate and illuminate our understanding of archipelagic identities in the eighteenth and nineteenth centuries ${ }^{21}$ ".

While some Ulster poets, impressed by the success of Robert Burns's publications, may indeed have sought to emulate him, readers also need to bear in mind the dialoging tendency of much long eighteenth-century verse, in which a discourse develops between poets, who in turn address similar subjects, allowing readers to become spectators, arbiters and contributors. Such literary discussion threads can continue and mature over several generations, by means of genres such as the verse epistle which, as William Dowling has argued, is frequently employed during the eighteenth century to "bring about the reconstitution of community in a world threatened by fragmentation and alienation"22.

One such sequence may be observed developing from Allan Ramsay's early eighteenthcentury work "The Poet's Wish", executed in the Scots "cherrie and the slae" stanza ${ }^{23}$. In this text Ramsay explores the routes by which happiness may be achieved however inauspicious the circumstances, concluding with the advice ${ }^{24}$ :

Mair speer na, and fear na,

But set thy Mind to rest, 
Aspire ay still high'r ay,

And always hope the best.

Towards the end of the century, Robert Burns utilises the same verse form in his "Epistle to Davie" where he discusses the love and friendship which offer him happiness despite the social inequalities that trouble him ${ }^{25}$. In the early nineteenth century, the Ulster poet and former United Irishman James Orr wrote an "Epistle to S. Thomson of Carngranny" which takes up those same themes but adds immediacy and realism to the discussion by referencing Orr's own shocking experiences in the 1798 Rebellion and demonstrating how he, as a poet, can celebrate and assert ownership of his own land despite the defeat of the United Irishmen ${ }^{26}$. Orr may have been writing within the same linguistic and epistolary tradition as Burns and Ramsay but far from settling for bland imitation of the Scots bards, crucially Orr extends, develops and adapts their theme of the pursuit of happiness and contentment to serve his own purpose, which is to address Irish issues. In his conclusion, within the context of the recent passing into law of the Irish Act of Union, Orr makes a defiant declaration of the social, literary and cultural independence of Ireland's labouring-class poets:

Tho' vain folk disdain folk,

We'se sing the burns an' bow'rs

o Airlan', our fair lan' -

Deel tak her faes an' ours!

That Orr was no more an imitator of Burns than Burns was of Ramsay and Fergusson before him was uncompromisingly asserted by John Hewitt. Furthermore, when one searches beyond the, of necessity, limited confines of the brief anthology Hewitt appended to his Rhyming Weavers one discovers a wealth of fine, thought-provoking and at times inspired verse - the works of a Scots-descended, northern school of Irish writers, male and female, who engaged dynamically with local, national and global issues, and with major literary movements in both vernacular and standard registers. These include Thomas Beggs (1798-1847) whose career and published output significantly developed the persona of the wandering romantic poet for his Ulster audience as he incorporated legend, myths and sublime North Coast seascapes into topographical works such as Rathlin ${ }^{27}$, or eerie, melancholy lyrics like "The Win' that Whistled in the Wa"'28. Also worthy of serious attention are Sarah Leech (1809-1830), commended by Frank Ferguson for her "satirical proto-feminist engagement with the authority of male writers" ${ }^{29}$; and Samuel Ferguson, described by W.B. Yeats, no less, as "the greatest Irish poet" and "the one Homeric poet of our time" ${ }^{30}$.

One further example must suffice to illustrate the surprising richness of the Ulster-Scots literary tradition. The poet is Florence Wilson (1874-1946) of Bangor, Co Down who remains, like Leech, an important and rare female voice. Wilson, best known for her stirring monologue "The Man from God Knows Where" about the executed United Irish leader Thomas Russell (1767-1803), was born Florence Addy, daughter of Robert Addy, the manager of a Lisburn linen mill. She married Frederick Wilson in Shore Street Presbyterian Church, Donaghadee in $1898^{31}$. In the period of the Easter Rising and of World War I Wilson produced a small volume of poetry titled The Coming of the Earls, dedicated to her son Niall, then fighting in the trenches on the Western Front. Many of her poems employ the Ulster-Scots vernacular with which she was familiar, having lived throughout her life in Antrim or Down. The following extract is typical in its appreciation, expressed in a self-evidently local voice, of the whin bushes so characteristic of the Ulster countryside: 
Whins

The whin is out afore the short day's turnin';

Och but the whin is brave!

It sets a ring o' fairy candles turnin'

Roun' dour Winter's grave

The whin is out when nothin' else is showin'

Along the dreepin' ditch

But, God above, he better loves its growin'

Than the red roses o' the rich ${ }^{32}$.

Wilson's collection references Irish history, folk beliefs and Home Front experiences, making it an intriguing entry in the Irish literary canon of both the Home Rule and the Great War eras. The following stanzas exemplify Wilson's power as a lyric poet:

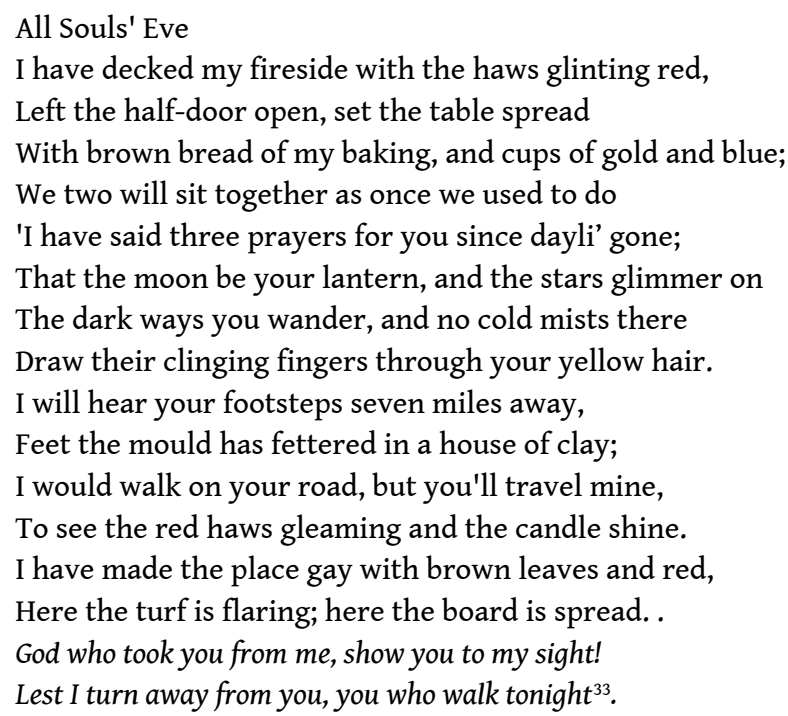

One notes the simplicity and apparent guilelessness with which the speaker evokes the cottage setting and its homely details, the Ulster Scots "dayli'gone" for "twilight", and the disturbing effect of the slow-paced revelation that a dark ritual proscribed by religious orthodoxies is being attempted. The speaker's concluding cry, commingling desperation, grief and anger will resonate with any reader who has lost a loved one, and must have proved potent for readers in the Lost Generation era of 1918, and during the early twentieth-century Irish struggles for independence. This is patently not a work that should be reserved for the appreciation of academics and archivists only.

21 In addition to a poetic tradition, Ulster has also produced significant prose works which again demonstrate original, individual character, though their models originate within the Scottish literary tradition. These include the nineteenth century novels of, for example, Archibald M'Ilroy" ${ }^{34}$, which have much in common with the Scots "kailyard school" of J. M. Barrie, S. R. Crockett and Ian MacLaren, often maligned (perhaps unjustly) for their narrow, sentimental, sanitised portrayal of Scotland. Ulster kailyard fiction represents life in rural Ulster and in Presbyterian-majority communities but demonstrates the capacity to address conflict, poverty and even tragedy with a degree of realism, albeit within the confines of a village universe.

Finally, it is important to stress that the Ulster-Scots literary tradition experienced a further flowering during the 1980s and 90s in the poetry, prose and language recovery work of Philip Robinson and James Fenton. Robinson published a descriptive grammar of Ulster Scots ${ }^{35}$, while James Fenton, a gifted Ulster-Scots poet ${ }^{36}$, produced The Hamely 
Tongue - another key text - his personal record of Ulster Scots as spoken in his native Co. Antrim ${ }^{37}$. Robinson is a founding member of the Ulster-Scots Language Society and has written original poetry and a trilogy of contemporary kailyard-style novels in UlsterScots, beginning with Wake the Tribe O' Dan ${ }^{38}$. His collection of poems, Alang tha Shore, employs Ulster-Scots language and traditional Scots stanza forms, while incorporating local, national and global political themes and making telling contemporary references ${ }^{39}$. In this respect he has followed in the tradition of the globally-aware Rhyming Weavers. The following extract from his poem, "Alba and Albania", is about the recent Balkan conflict and provides a suitable example of his work. Here he draws a parallel with the Ulster "troubles" presenting the warring factions of Bosnia in terms that correspond to Anglican, Dissenter and Catholic in the north of Ireland, and starkly drawing attention to the grief and bitterness which result from violent confrontation:

Ticht wee Serbs, tha peep-o-day clan.

Mooslim dissenters, black-moothed an thran

Papish Croatians bigged thair ain laun,

Thirteen an Echtie-Nine.

Weemin girnin owre deid guidman

Wrangs aye in min $^{\prime 40}$.

From the discussion above, it should be clear that there exists a rich field of Ulster-Scots literature, exhibiting both sophistication and gravitas, for post-primary pupils in Ulster to engage with intellectually and upon which to hone their critical skills. That this is not happening appears all the more surprising, given political developments which appear to have created an Ulster-Scots friendly climate. The Belfast (Good Friday) Agreement of $1998^{41}$, and the St Andrews Agreement of 2006 committed the Northern Ireland executive to a strategy for developing the Ulster-Scots language, including its attendant culture which surely includes the literary tradition ${ }^{42}$. In addition, the European Charter for lesser used languages signed by the British Government in 2001 accords protected (Part 2) status to Ulster Scots ${ }^{43}$. The Ulster-Scots Agency, a cross-border body with a language, history and culture brief, was established as a result of the Good Friday Agreement and in 2011 the Ministerial Advisory Group for an Ulster-Scots Academy (MAGUS) was inaugurated under the auspices of the Department of Culture, Arts and Leisure (DCAL). A major aspect of the latter's purpose is to develop strategies for and to fund projects in Ulster-Scots under specified work streams, including Language and Literature, and Education and Research. MAGUS members include academics, published experts, representatives of Ulster-Scots "stakeholder" organisations, and members of the UlsterScots community. Strategic aims involve "building knowledge and understanding of the Ulster-Scots tradition in Ireland, Scotland and beyond; promoting coherence within the Ulster-Scots sector; securing the broadest possible support for the sector and its work across the community ${ }^{44 "}$. The current DCAL Minister, Sinn Fein's Carál Ní Chuilín, has maintained a supportive interest in the MAGUS, and has met with the group and its subgroups as they seek ways forward in delivering its remit. She has demonstrated keen awareness of the historo-cultural links between the island of Ireland and its Scottish neighbour, which are recognised as significant for both nationalist/republican and unionist/loyalist communities in Ulster.

MAGUS funding has enabled several important academic research projects which are of relevance to post-primary education. Frank Ferguson, currently Director of the University of Ulster's Centre for Irish and Scottish Studies, has overseen schemes which have significantly taken forward the recovery of much Ulster-Scots literature, facilitating 
scholarly and popular appreciation of its quality through digitisation of key texts, many of which may now be accessed through the Project websites ${ }^{45}$. The digitisation projects have demonstrated the liveliness of the Ulster-Scots literary tradition well into the twentieth century. Other Project work has included the production of an edited reader of Ulster-Scots poetry, and of an Ulster-Scots literary encyclopaedia, both forthcoming. The latter two volumes are likely to be of great interest to scholars, but are also designed to develop awareness and understanding of this north of Ireland literary tradition, and of its Scottish ancestry, among post-primary school pupils and their teachers. Already, one of the most successful aspects of the Project has been the establishment of an impact programme of school-based workshops which has to date introduced Ulster-Scots poetry to some 1000 young people. Students and teachers alike have responded with great enthusiasm when presented with examples of the texts for close reading ${ }^{46}$.

Currently, however, indigenous Ulster-Scots literature though demonstrably a rich, genuine field for study, is excluded from the official curriculum in schools in the north of Ireland. The Ulster-Scots Poetry Project team has gained access to school-based audiences through offering to teach the principles of poetry appreciation required by the GCSE and A level English Literature examination specifications, and by creatively employing UlsterScots literary texts to illustrate examples of poets crafting their work. The following quotation from Samuel Ferguson's "The Fairy Thorn", to take but one example, was chosen to demonstrate how the poet had incorporated a high concentration of literary devices such as sibilance, assonance, repetition, alliteration, and rhyme in order to evoke an eerie, mysterious and hypnotic atmosphere ${ }^{47}$ :

But solemn is the silence of the silvery haze

That drinks away their voices in echoless repose,

And dreamily the evening has still'd the haunted braes,

And dreamier the gloaming grows.

Given that young people often find the poetry sections of their examination intimidating, particularly when previously unseen poetry must be discussed and analysed, the Project team's approach has proved very successful. Return invitations have been extended by almost every school. This is of course a highly satisfactory outcome for all concerned, but nevertheless it is surprising, even astonishing, that the Ulster-Scots poets are not explicitly acknowledged within the Northern Ireland curriculum. What other national literature dare not speak its name but has to gain entry to the classroom under cover of the faintly sinister-sounding "unseen poem"?

There are many reasons for this unsatisfactory state of affairs which could be debated at length. For example, the Ulster-Scots language has become implicated in Ulster's "culture wars"; as Frank Ferguson explains in the introduction to his anthology Ulster-Scots Writing : "it tends to be perceived as the preserve of one tradition [...]. Ulster-Scots is viewed as part of the Unionist, Planter and Protestant set of cultural belongings, in opposition to Nationalist, Republican, Catholic and Gaelic cultural inheritance ${ }^{48}$." In popular parlance it has been referred to as "a DIY language for Orangemen". Certainly, the awarding of European Charter protected status to Ulster Scots in 2001 generated considerable controversy among some linguists but also more widely ${ }^{49}$. The move has been suspected as a cynical political ploy, adopted as a means of sweetening for some loyalists the perceived "greening" of Northern Ireland in the wake of the Belfast Agreement. If that was indeed the case, it has spectacularly failed among one politically-unionist grouping the well-heeled, professional and commercial Protestant middle class, many of whom 
adhere to the view of Ulster-Scots as "bad English", and deplore the employment of public funds in its support. In such a climate the excellent, politically pluralist, indigenous literary tradition can become a casualty in wrangling among people who may never have read a line of Orr, Leech, Ferguson or Fenton.

A further factor inhibiting the community's willingness to embrace Ulster-Scots literature is the "cultural cringe" factor associated with the culture of music, dance and popular comic verse that sometimes attends the language tradition. Across the community it is often derided as backward-looking, farmyard-oriented and irrelevant to the "cool" generation of the early twenty-first century. Yet in response one might ask, are Heaney's poems about his rural experience similarly marginalised? Are Yeats's literary forays into Irish legend and myth thus summarily dismissed? The answer is of course "no" to both questions, because in the classroom, where such works are accorded the respect they deserve, talented teachers have consistently demonstrated their continuing relevance.

Education which offers a proper knowledge, understanding and appreciation of the breadth and subtlety of much Ulster-Scots literature is of course the way forward, therefore it is all the more crucial to ensure that the curriculum followed by young people in the north of Ireland permits their engagement with it. The present writer does not purport to argue for Ulster-Scots medium education, or for teaching children to speak in Ulster-Scots - though there are arguments for both which others may wish to make and which are entitled to a hearing and to rational discussion. The intention here, however, is to call attention to the education system's failure to acknowledge and foreground the striking and original texts within the Ulster-Scots literary tradition. These, as demonstrated above, far from following a merely local, even parochial trajectory, explore universal human questions and issues with subtlety, intricacy and demonstrably fine crafting. Kathryn White, a member of the Ulster-Scots Poetry Project research team and a lecturer at the University of Ulster, has a background in Irish Literature of the Modernist period and a published monograph on Samuel Beckett ${ }^{50}$. She is in no doubt that these works are worthy of sustained attention from scholars and from the public. She comments:

Ulster-Scots Literature is aesthetically rich and provides an important insight into the cultural and literary history of the North of Ireland. Marginalised, discounted and ridiculed, Ulster-Scots Poets have often been overlooked in discussions regarding scholarly poetry, and we have done a great disservice to generations of students who have passed through our education system with no knowledge of their own literary heritage. These poets, through their use of the vernacular, celebrate a shared culture with Scotland while also identifying themselves as Irish. If we are to comprehensively understand the development of writing in Ireland it is imperative that Ulster-Scots Literature is examined and discussed ${ }^{51}$.

30 All schools in Northern Ireland follow a curriculum devised and determined by the Belfast-based Council for the Curriculum Examinations and Assessment (CCEA) which reports to the Department of Education. In post-primary education the curriculum develops in three key stages according to age, beginning with KS3 (for 11-14 year old pupils $)^{52}$. At this level schools have a degree of freedom with regard to determining subject content but are required to teach and assess certain key skills: communication, use of information technology, using Mathematics and several "thinking and personal capability skills", such as "improving learning and performance", or "working with others". The next level, KS4 (14-16), includes GCSE and Entry Level qualifications which 
pupils may take in a fairly wide range of traditional and more contemporary subjects, such as Drama, Journalism or Media Studies ${ }^{53}$. The final stage, KS5 includes A Levels but also other vocational and Key Skills qualifications. Normally three or four A Levels are taken, often as a prelude to study at university.

The curriculum at all levels is underpinned by key themes, for example "Personal Understanding", explained by CCEA as follows: "This theme provides opportunities for pupils to explore their sense of identity and to examine some of the factors influencing their identity. Pupils should also develop a deeper sense of self and an awareness of and respect for the diversity that exists around them ${ }^{54}$ ". In fact the discourse of a diversity and inclusion agenda may be readily extrapolated from many of the pages accessible on the Northern Ireland curriculum website. On that basis alone one might legitimately question the exclusion of the Ulster-Scots literary tradition. However, witness the following instruction to teachers regarding the choice of appropriate texts for GCSE English Literature. The specifications overtly state that students are to be encouraged to: "understand that texts from English, Welsh or Irish literary heritage have been influential and significant over time, and [to] explore their meaning today." They are also expected to "explore how texts from different cultures and traditions may reflect or influence values, assumptions and sense of identity" ${ }^{55}$.

In practice what this means, for example, is that while the poetry selections include significant English, Irish and Welsh writers such as Hardy, Heaney, Yeats, John Clare, RS Thomas et al, no Ulster-Scots poet features. Nor does Robert Burns, who is a major British, not simply a Scottish poet, and who furthermore is regarded and revered as a "true poet of the people" by adherents of all traditions throughout Ireland ${ }^{56}$. Modern, major Scottish poets with international reputations do not feature either, with Edwin Muir's poem "The Castle" the single exception. Finally, with regard to fiction, "heritage" prose texts are defined as from England, Ireland or Wales. Thus, the Scottish novelist R.L. Stevenson's, Kidnapped or Treasure Island, for example, would be regarded as a text from a different culture. This is a wholly ludicrous state of affairs, with Ulster literature excluded and the local community's Scottish heritage, a well-documented part of the history of the north of Ireland since pre-historic times, implicitly denied. That being the case, one must conclude that the Literature curriculum is insufficiently nuanced to serve the needs of northern Irish young people studying literature in a post-Belfast Agreement, pluralist north of Ireland. There are, however, ways forward which might remedy the current less than satisfactory situation.

At Key Stage 3, Ulster-Scots literature might be introduced to 11-14 year olds by means of activities which would teach the requisite skills, detailed above. An example of such a teaching resource, based on James Orr's vernacular poem "The Wanderer" may be accessed via the Ulster-Scots Poetry Project website ${ }^{57}$. The suggested activities are referenced to the Northern Ireland Curriculum learning areas and to the skills and capabilities framework. This resource has already been successfully trialled in UlsterScots Poetry Project school workshops.

34 A further measure would involve minor adjustments to GCSE and A Level subject specifications but would allow their extension to incorporate Ulster-Scots literature. The set GCSE poetry anthologies, for example, currently replete with works by Heaney, Hardy, Yeats, Blake, Betjeman et al, might also feature individual works by, say, Orr, Wilson or Fenton. Indeed in the light of the emphasis within the GCSE literature curriculum on "heritage" texts, accommodation of the Ulster-Scots literary inheritance, far from being 
merely desirable, should surely carry the force of an imperative. Thirdly, at A Level, an optional Ulster-Scots poetry module might be introduced into the literature specification. This would enable those young people and their teachers who wish to do so, to examine a broad range of high quality Ulster-Scots texts within their literary, historical, biographical and cultural contexts, just as, for example, Geoffrey Chaucer or Alexander Pope are currently taught. There are, clearly, several such doorways of opportunity within the Northern Ireland curriculum as it currently stands, particularly since the British Education Secretary, Michael Gove, recently freed the examination specifications in Northern Ireland and Wales from centralised control ${ }^{58}$.

In a further welcome development, the University of Ulster has recently received funding from the MAGUS for a major Education project that has the potential to put Ulster-Scots literature directly into the classroom. The Education Project team are to develop curriculum materials for post-primary learners, concentrating on Key Stages 3, 4, and 5 by March 2015. The team is committed to designing resources that will clearly conform to the pedagogical approaches which are integral to the current (revised 2007) Northern Ireland Curriculum. To ensure quality and excellence all materials will adhere to the standards laid down by CCEA. In design, the materials will be flexible, accessible and attractive to teachers and to learners, while in order to ensure efficient delivery in the classroom, provision will be made for the resourcing and empowering of post-primary teachers through training programmes and workshops. As the Project team are well aware, relevance to current curriculum and examination specifications will be key to making any new resources attractive to teachers. Project research will in addition greatly extend the range of actual Ulster-Scots literary texts available since a further 100, including prose works, are to be digitised. This is undoubtedly an exciting initiative which will harness the expertise in Ulster-Scots literary research and in teacher education that is already present within the University of Ulster. Through partnership approaches, the Project team will also draw on the skills and scholarship of literary, history, education and digitisation academics at Queen's University Belfast and the University of Glasgow.

Two factors will be vital in ensuring Project success. First, materials produced must be endorsed by the Department of Education. Secondly, CCEA's authentication of the resources must be secured. Links to the Project materials from the CCEA website, and explicit assurances from the Curriculum authority regarding their appropriateness for the delivery of requisite skills and competencies will be vital. Education Project directors at the University of Ulster must take steps to engage with curriculum managers within CCEA at a very early stage; discussions should include clear practical strategies and mechanisms for the trialling, roll-out and uptake of the new resources. Conversely, it is incumbent upon both the Department of Education and CCEA to facilitate and promote access to the materials. At the very least they must be readily visible and available, and the heritage they represent must be explicitly respected.

In addition to ensuring the inclusion of Ulster-Scots literature within current specifications, a further outcome might be the development of a GCSE and ultimately an A level in Ulster-Scots Studies. These would permit detailed engagement with all aspects of the Ulster-Scots tradition in literature, language, history and culture, but such a project would likely require a period of ten years to complete, so action to accommodate UlsterScots literature within the curriculum as it currently stands should not be further delayed. 
In recent months, the government of the Republic of Ireland has unveiled its new passport, the text of which integrates quotations from the poetry of James Orr alongside specially commissioned accompanying artwork ${ }^{59}$. South of the Border then, Orr, a Presbyterian Ulster-Scots poet, has been publicly acknowledged as a significant literary figure for the whole island. The message for Department of Education and Curriculum authority chiefs in the north could hardly be clearer.

\section{NOTES}

1. James Orr, "The Irish cottier's death and burial", The posthumous works of James Orr, Belfast, Francis Finlay, 1817, p. 70-77.

2. Jonathan Bardon, A History of Ulster, Belfast, Blackstaff Press, 2001, p. 17-24.

3. Ian McBride, Scripture Politics: Ulster Presbyterians and Irish Radicalism in the Late Eighteenth Century, Oxford, Oxford University Press, 1998, p. 66 \& p. 69.

4. Angélique Day, P. McWilliams and N. Dobson (eds.), Ordnance Survey Memoirs of Ireland: Volume Twenty-six, Parishes of Co. Antrim X 1830-1, 1833-5, 1839-40, Belfast, The Institute of Irish Studies, Queen's University, 1994, p. 106, p. 107 \& p. 103.

5. Quoted in John Hewitt, Rhyming Weavers and Other Country Poets of Antrim and Down, Belfast, Blackstaff Press, 1974, p. 17.

6. J.R.R. Adams, The Printed Word and the Common Man: Popular Culture in Ulster 1700-1900, Belfast, Institute of Irish Studies, Queen's University, 1987, p. 175-181.

7. Brendan Adams (ed.), Ulster Dialects: An Introductory Symposium, Cultra, Ulster Folk Museum, 1964.

8. Carol Baraniuk, "Disagreeably Scottish?", The Drouth, 19, Spring 2006, p. 13-17. This essay includes a more detailed summary of the work of the mid-twentieth-century linguistic researchers.

9. John Braidwood, "Ulster and Elizabethan English", in Brendan Adams (ed.), Ulster Dialects: An Introductory Symposium, op. cit., p. 47.

10. Brendan Adams, Introduction to Ulster Dialects, op. cit., pages not numbered.

11. John Corbett, Language and Scottish literature, Edinburgh, University Press, 1997, p. 5-6.

12. John Hewitt and John Montague, The Planter and the Gael, Belfast, Arts Council of Northern Ireland, 1970.

13. John Hewitt, “Once Alien Here”, Selected Poems, Belfast, Blackstaff Press, 2007, p.8.

14. John Hewitt, Rhyming Weavers, op. cit., p.2.

15. Samuel Thomson, "To Captain M’Dougall, Castle Upton", Simple Poems on a Few Subjects , Belfast, Smyth and Lyons, 1806, p. 37-39.

16. David Herbison, “The auld wife's lament for her teapot”, John Hewitt (ed.), Rhyming Weavers, op. cit., p. 170-72.

17. Frank Ferguson (ed.), Ulster-Scots Writing: An Anthology, Dublin: Four Courts Press, 2008. 
18. D. J. O'Donoghue, "Ulster poets and poetry", Ulster Journal of Archaeology (second series), 1, 1895, 1, p. 20-22.

19. Brian MacLoughlainn, "The guid guide to finding that elusive Ulster-Scots", Irish News, 26 September, 1996.

20. Liam McIlvanney, Burns the Radical: Poetry and Politics in Late Eighteenth-century Scotland, East Linton, Tuckwell Press, 2002, p. 226.

21. Liam McIlvanney, "Across the narrow sea: the language, literature and politics of Ulster-Scots", in Liam McIlvanney and Ray Ryan (eds.), Ireland and Scotland: Culture and Society, 1700-2000, Dublin, Four Courts Press, 2005, p. 203-226 \& p. 214-5.

22. William Dowling, The Epistolary Moment: The Poetics of the Eighteenth-century Verse Epistle , Princeton University Press, 1991, p. 11.

23. A fourteen line stanza which incorporates a complex rhyme scheme and employs sophisticated variations in its metrical pattern.

24. Martin Burns and John Oliver (eds.), The Works of Allan Ramsay, 6 vols., Edinburgh, The Scottish Text Society, I, 1951, p. 243-44.

25. James Kinsley (ed.), Burns Poems and Songs, Oxford University Press, 1971, p. 49-53.

26. James Orr, Poems on Various Subjects, Belfast, Smyth and Lyons, 1804, p. 101-04.

27. Thomas Beggs, Rathlin: A Descriptive Poem, Written after a Visit to that Island, Belfast, Hugh Clark, 1840.

28. Thomas Beggs, The Second Part of the Minstrel's Offering: Original Poems and Songs, Belfast, Hugh Clark, 1836, p. 20-22.

29. Ulster-Scots Writing: An Anthology, op. cit., p. 207.

30. W.B. Yeats, "The poetry of Sir Samuel Ferguson 1" and, "The poetry of Sir Samuel Ferguson 2", in J.P. Frayne (ed.), W.B Yeats: Uncollected Prose 1, New York, Columbia University Press, 1970, p. 81-7, p. 87 \& p. 88-104, p. 89-90.

31. This and all websites referenced accessed 16 November, 2013.

32. Florence Wilson, The Coming of the Earls, Dublin, Candle Press, 1918, p.19.

33. Ibid, p.18.

34. Archibald M'Ilroy, The Auld Meetin'hoose Green, Belfast, 1898.

35. Philip Robinson, Ulster-Scots: A Grammar of the Traditional Written and Spoken Language, Belfast, Ullans Press, 2007.

36. James Fenton, Thonner an Thon: An Ulster-Scots Collection, Belfast,Ullans Press, 2000 and On Slaimish, Belfast, Ullans Press, 2009.

37. James Fenton, The Hamely Tongue, Belfast, Ulster-Scots Academic Press, 1995.

38. Philip Robinson, Belfast, Ullans Press, 2000.

39. Philip Robinson, Alang tha Shore, Belfast, Ullans Press, 2005.

40. Ibid., p. 12-15.

41. <http://cain.ulst.ac.uk/events/peace/docs/agreement.htm>

42. <www.dfa.ie/uploads/documents/st_andrews_agreement.pdf>

43. Link to website of dcalni.

44. Link to website of dcalni.

45. Link to Ulster poetry ; Link to Ulster-Scots poetry 
46. The following response, from a Head of Department at a respected Ulster grammar school is typical: "thanks for a fantastic lecture on Friday - it was one of the most relevant and engaging presentations I have ever witnessed by visiting speakers to school!" Email communication to the present writer.

47. Samuel Ferguson, Lays of the Western Gael and Other Poems, London, Bell and Daldy, 1865, p. 105-09, p. 107.

48. Frank Ferguson, Ulster-Scots writing: An Anthology, op. cit., p. 1-2.

49. John Kirk: "Does the United Kingdom have a language policy?", in Journal of Irish Scottish studies, Volume 1, Issue 2, March 2008, p. 205-222, p. 205.

50. Kathryn White, Beckett and Decay, New York, Continuum International Publishing, 2009.

51. Email to present writer, 20 October, 2013.

52. <http://www.nicurriculum.org.uk/>

53. Entry level qualifications may be taken by pupils not deemed ready for GCSE level work.

54. Link to nicurriculum.org.

55. CCEA GCSE Specification in English Literature, p. 3. Accessible at: <http:// www.rewardinglearning.org.uk/index.aspx $>$ Use Qualifications Quickfind search facility.

56. Carol Baraniuk, "The great enchanter", Fickle Man: Robert Burns in the $21^{\text {st }}$ Century, Dingwall, Sandstone Press, 2009.

57. <http://www.arts.ulster.ac.uk/ulsterscotspoetry/resources.html>

58. <http://www.bbc.co.uk/news/uk-22865313>

59. <http://www.bbc.co.uk/news/uk-northern-ireland-24329731>

\section{ABSTRACTS}

Since John Hewitt's mid-twentieth century research stimulated interest in the "rhyming weavers", awareness has been growing among scholars of the richness of the Ulster-Scots literary tradition. This essay considers historic and linguistic connections between the north of Ireland and Scotland, and discusses the nature of the relationship, often misrepresented, between Ulster vernacular poetry and the works of Robert Burns. The essay demonstrates the excellence of much Ulster-Scots verse and challenges the educational establishment's failure actively to encourage young people to engage with this aspect of the north of Ireland's cultural heritage. The case is argued for several opportunities which would permit the current unsatisfactory situation to be addressed directly by students and teachers in the post-primary classroom.

Depuis que la recherche de John Hewitt au milieu du XXe siècle a stimulé un intérêt pour les "rhyming weavers », les milieux universitaires ont été plus sensibles à la richesse de la tradition littéraire Ulster-Scots. Cet article explore les connections historiques et linguistiques entre le 
nord de l'Irlande et l'Ecosse, et examine la nature des rapports, souvent presentés de manière déformée, entre la poésie vernaculaire d'Ulster et l'oeuvre de Burns. L'article démontre l'excellence d'une grande partie de la poésie Ulster-Scots et s'interroge sur le fait que les décideurs du monde éducatif aient choisi de ne pas encourager les jeunes à prendre en compte cet aspect de l'héritage culturel du nord de l'Irlande. L'article avance plusieurs pistes qui permettraient aux étudiants et aux enseignants du secondaire de rectifier cette situation peu satisfaisante.

INDEX

Keywords: education, collective identity, cultural heritage, poetry, Northern Ireland, Rhyming Weavers, Ulster-Scots, Ireland/Scotland relations

Mots-clés: héritage culturel, Hewitt John, poésie, identité collective, Irlande du Nord, relations Irlande/Ecosse, Burns Robert

\section{AUTHOR}

CAROL BARANIUK

University of Ulster 